\title{
BOTH SIDES OF SELECTION
}

Finding and filling jobs in nursing and the health services

MARTIN EDIS

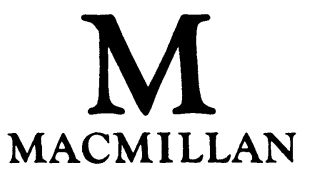


(C) Martin Edis and Nursing Times 1990

All rights reserved. No reproduction, copy or transmission of this publication may be made without written permission.

No paragraph of this publication may be reproduced, copied or transmitted save with written permission or in accordance with the provisions of the Copyright, Designs and Patents Act 1988 or under the terms of any licence permitting limited copying issued by the Copyright Licensing Agency, 33-4 Alfred Place, London WC1E 7DP.

Any person who does any unauthorised act in relation to this publication may be liable to criminal prosecution and civil claims for damages.

First edition 1990

Published by

MACMILLAN EDUCATION LTD

Houndmills, Basingstoke, Hampshire RG21 2XS

and London

Companies and representatives

throughout the world

Typeset by Footnote Graphics,

Warminster, Wiltshire

British Library Cataloguing in Publication Data

Edis, Martin

Both sides of selection : finding and filling jobs in nursing and the health services.

1. Great Britain. Health services. Personnel. Recruitment.

I. Title

362.10683

ISBN 978-0-333-54239-2 ISBN 978-1-349-12095-6 (eBook)

DOI 10.1007/978-1-349-12095-6 
For Claire 


\section{CONTENTS}

List of figures

$x i$

Preface

xii

Acknowledgements

xiv

PART ONE THE CANDIDATE

The day of judgement - the initiation

Chapter 1 Perspectives on selection

The tradition of interviewing

The compliant nurse

Why the mystery?

The job search in the nineties

The key processes

Chapter 2 Making a job change

Why things cannot be the same afterwards

Know what you want

The diagnosis

Chapter 3 Targeting the opportunity

Finding jobs

What you can tell from advertisements $\quad 29$

Making direct contact

Chapter 4 The informal visit

Why an informal visit? 
How to behave $\quad 37$

Meet those working there $\quad 37$

What to look out for 38

Avoiding being grilled 39

Chapter 5 Presenting yourself on paper 41

Setting out your stall - an analogy 41

Preparation 41

The application form $\quad 44$

The CV 44

The accompanying letter $\quad 49$

Chapter 6 The candidate selection process overall 52

Overview of recruitment stages 52

Closing date for applications $\quad 53$

Shortlisting meeting $\quad 53$

Invitations to the interview 54

Interview dates 54

Dates of other assessments $\quad 54$

Taking up of references $\quad 55$

Medical checks $\quad 55$

Offer of post(s) to successful candidate(s) 55

Letters of 'regret' to unsuccessful candidates 56

Chapter 7 All about the interview 57

What you are in for $\quad 57$

Their objectives $\quad 58$

Interview judgements $\quad 59$

They will be in control 59

First impressions count $\quad 59$

The common pattern 60

What is the employer looking for? 61

Chapter 8 Honest self-appraisal 64

First stage: how do you compare? 64

Second stage: assessing scope for development in the job $\quad 65$

Third stage: deciding if you are a viable candidate 65

Fourth stage: identifying your strategy 65

Skeletons in the cupboard 66 
Chapter 9 Preparing for the interview 69

$\begin{array}{ll}\text { Your interview agenda } & 69\end{array}$

The interviewers' cues $\quad 70$

Preparation stage by stage $\quad 73$

$\begin{array}{ll}\text { Types of interview } & 79\end{array}$

Chapter 10 Selection for senior and managerial posts

Organisational ritual $\quad 81$

The trial-by-sherry party $\quad 82$

Preliminary work $\quad 83$

Interview arrangements for management posts $\quad 84$

$\begin{array}{ll}\text { Psychometric testing } & 85\end{array}$

Assessment centres $\quad 86$

$\begin{array}{ll}\text { The tour } & 87\end{array}$

Chapter 11 Assorted interview hazards 89

$\begin{array}{ll}\text { Twelve in a room } & 89\end{array}$

The company of wolves $\quad 89$

Twelve in a day $\quad 90$

Fitting in and fobbing off $\quad 91$

Some other discriminatory ploys $\quad 91$

The halo or the horns $\quad 92$

Chapter 12 Perils of being an insider 93

Preparation hints for internal candidates $\quad 98$

Chapter 13 On the day - the interview 101

Dress and appearance 101

Getting there 101

Making your entrance 103

Body language $\quad 103$

Answering questions $\quad 103$

Control 104

Leaving the right impression $\quad 105$

When you get the offer 106

If you don't get the offer 108

Suspicions of discrimination 108

PART TWO THE SELECTOR 111

The day of judgement - the ritual 115 
Chapter 14 Perspectives for the selector

The survival of interviewing

The job search in the nineties

The key processes

Chapter 15 Selection basics

Specify the requirements

Criteria need to be relevant and assessable

Use good methods for gathering evidence

Develop operational skills

Make sound judgements and evaluations

The selection context

128

Consider the impact on candidates

Chapter 16 Clarifying the requirements

What is needed?

Who is wanted?

Sharpening criteria

Using the personnel officer

Chapter 17 Selection strategy

Choosing a selection device

Application forms

Higher hurdles?

Finding better signals of future success 151

Not saying but doing

Chapter 18 The recruitment selection process overall

The essentials

Key stages

156

Administration

The trend to complication

Chapter 19 Advertising the job

The advertisement itself

Which medium?

Record the response

The recruitment information package

164

Equal opportunities considerations 
Chapter 20 Preliminary screening 170

Deciding to shortlist $\quad 170$

Information from the application form $\quad 170$

Using criteria as a framework $\quad 172$

References 172

Chapter 21 Key skills for the interviewer 177

Gathering evidence using questions 177

$\begin{array}{ll}\text { Listening } & 184\end{array}$

Rapport 184

$\begin{array}{ll}\text { Control } & 186\end{array}$

$\begin{array}{ll}\text { Preparation } & 188\end{array}$

Chapter 22 Gathering evidence - assessment against criteria 191

Competence 191

Commitment criteria 192

Classifying evidence against criteria 196

Chapter 23 Interviewing internal candidates 198

An obvious match? 198

Using what you already know 199

Chapter 24 Coming to a decision 206

What went wrong? 206

Obtaining good evidence 208

Common errors of judgement 213

Judging and evaluating 215

Making the offer 217

Chapter 25 After the interview 220

Deciding to give feedback $\quad 220$

What individuals might want 221

Feedback, advice or counselling? 223

Differing aims in post-interview counselling 223

Practical issues $\quad 226$

The day of judgement - epilogue 231

Appendix 1 Criteria-based interview assessment form 232

Appendix 2 Nursing competencies 233 
Appendix 3 List of useful addresses

Appendix 4 Index to checklists and summary charts

235

237

Index

239 


\section{LIST OF FIGURES}

Flowchart A The selection process for the candidate 2

Figure 2.1 Job change summary chart 25

Figure 3.1 Job finding summary chart 35

Figure 5.1 The conventional CV 47

Figure 5.2 The accompanying letter 50

Figure 5.3 Application form and CV summary chart 51

Figure 8.1 Self-appraisal summary chart 68

Flowchart B The selection process for the selector 113

Figure 15.1 Selection basics summary chart 129

Figure 24.1 Decision-making summary chart 219

Figure 25.1 Post-interview feedback summary chart 230 


\section{PREFACE}

This book has been written for all of the parties involved in selection. It is about how to manage the selection process, whether you be a candidate or a selector.

It is written primarily for people in the nursing profession, but its contents are equally applicable to other professionals, particularly those working in the UK National Health Service.

I shall concentrate a great deal on the source of most people's concerns - the interview. I will explain how it can be conducted most effectively, and give advice to candidates on how they can put themselves across confidently.

Nearly everyone has memories of interviews that have been gruelling and frustrating rituals, neither positive nor useful. My objective is to ensure that the interview process will not be an ordeal nor an exercise in miscommunication, but that, at least some of the time, it will become a rewarding and useful experience for all parties.

Generally, I have used the female gender in this book, as doing so is appropriate in the context I am writing about. Readers are, of course, free to substitute 'he' for 'she' where they so desire.

Part One of this book is written for candidates, and Part Two for selectors. However, there is material throughout the book to interest both parties. Readers will also find some similarity between Chapters 1 and 14. This is because the issues covered are relevant to both parties, and the material has been repeated for completeness.

To illustrate many aspects of the selection process, I will be 
asking you to follow the progress of Sally Robinson, candidate, and Shirley Garnett and Miss Williams, interviewers. Their experiences are described in a narrative called 'The day of judgement'. This appears in instalments at the beginning of Part One and Part Two, and it is concluded at the end of Chapter 25. 


\section{ACKNOWLEDGEMENTS}

Several of the chapters in this book appeared in their original form in Nursing Times. I would like to express my gratitude to several of the original authors for agreeing to let me use and adapt their material in this book.

The authors to whom thanks are due are Jane Schober ${ }^{1}$ (for parts of Chapter 2), Ray Rowden ${ }^{2}$ (for parts of Chapter 3) and Anne Smith $^{3}$ (for much of Chapter 25). Chapters 12 and 23 include original articles by Jill Fardell and Andrew Cole, both of Nursing Times, which I have used in their entirety. Jill Fardell commissioned the original series of articles and provided many ideas and much advice on the development of this book. I must give particular thanks to Jill Baker, who contributed Chapter 5 and offered invaluable help with the text.

${ }^{1}$ Jane Schober MN SRN RCNT DipN (Lond) DipNEd RNT is Principal Lecturer (Nursing) at Leicester Polytechnic.

2 Ray Rowden SRN RMN ONCNC MBIM LHSM is general manager, priority services, West Lambeth Health Authority, and an associate editor of Nursing Times.

${ }^{3}$ Anne Smith RGN is assistant general manager (central community services) in the Acute and Community Services Unit, East Surrey Health Authority. 